\title{
School Leadership Style in Improving Teacher Performance in State SD 56 Banda Aceh
}

\author{
Nurmiati, ${ }^{1}$ Murniati ${ }^{2}$, Bahrun $^{2}$ \\ Principal of SD Negeri 56 Kota Banda Aceh, Indonesia ${ }^{1}$ \\ Master of Education Administration Study Program, Postgraduate Program, \\ Syiah Kuala University, Indonesia ${ }^{2}$ \\ \{putrinurmiati@gmail.com\}
}

\begin{abstract}
In implementing leadership style programs to improve teacher performance, this program is very important for both students and students. The purpose of this study is to find out: formulation programs, implementation of strategies, and improvement programs. This study uses a descriptive method with a qualitative approach. Data collection techniques: observation, interviews, and documentation studies. The subjects of this study were principals, supervisors, and teachers. (1) Leadership style in improving teacher performance, the formulation begins with monitoring or analysis carried out by the principal, the supervisor. Applicable KEMENDIKBUD regulations and curriculum regulations guide programs that are compiled, long-term programs, all programs. The competencies are possessed by the principle which is contained in the leadership style of the principal to improve teacher performance; (2) The principal implements leadership style programs in improving teacher performance; (3) What are the obstacles that are faced in implementing leadership style in improving teacher performance rather than the personality rather than the teacher itself.
\end{abstract}

Keywords: Leadership Style, Principal, and Teacher Performance.

\section{Introduction}

Indonesia's national education aims to develop the potential of students to become human beings who believe and devote to God Almighty, have noble character, are healthy, knowledgeable, capable, creative, independent and become citizens of a democratic and responsible state as stated in the Law No. 20 of 2003 [1] concerning the national education system in article 1. To achieve this goal an Indonesian national education system was established which was carried out to the nation's cultural and philosophical roots with an orientation towards global competition in the progress of world civilization through national education management.

Mulyasa[2] said: "The occurrence of various community changes and the multidimensional crisis that has long hit Indonesia has made it difficult to find the ideal leader who has a high commitment to his duties and responsibilities. Many fields of life are met by leaders who are less qualified to carry out the mandate of their leadership. Likewise in education, not a few amateur, educational leaders who do not have a clear vision and mission about the educational institutions or schools they lead. This, of course, needs serious handling because educational leadership is very important in building effective schools". To improve the quality of education as expected, not only the role of the teacher is demanded, but the principal is also very instrumental in it. The principal is as a leader or top manager at his school. He is the driving force of all available resources in schools, both teacher resources, administrative staff, and 
students. Thus the teacher, the principal must be able to influence, encourage, direct the teacher so that they carry out their duties optimally. Thus, the role that is highly expected from the principal is effectiveness or management of the school principal in moving the teachers.

Effective principals are principals who have a variety of abilities and competencies that are adequate. Karwati \& Priansa [3] said that principals' leadership was constructed on five dimensions that are important for each school principal: (a) Educational capabilities (educational capabilities; (b) Personal capabilities; (c) Relational abilities (relational capabilities); (d) intellectual capabilities; and (e) organizational capabilities. Sagala [4] said that the characteristic of the principal's leadership was to have a high work morale and was visionary characterized by (1) correctly understanding the various aspects of school activities by using cognitive and reasoning power regularly and intensively; (2) responsive to various changes in knowledge and technology; (3) effective communication skills; (4) looking at school interests as a whole; (5) thinking and acting rationally and objectively; and (6) able to determine priorities sharply. With the management of the principal's leadership, it will be able to improve teacher professionalism.

From some of the above meanings, it can be concluded that the leadership of the principal is related to the ability and competence of the head as if both hard skills and soft skills to influence all school resources to be able to achieve the goals and objectives set by the school. Principal leadership that can be said to be effective is leadership that can empower all the potential that exists in the school, and the purpose of this study is to find out: program formulation, implementation of strategies, and barriers faced by principals in implementing staffing service improvement programs.

\section{Method}

The approach used in this study is a qualitative approach using descriptive. Descriptive research methods in research methods that aim to describe the condition of the research field at present or when the research was conducted. Data collected is analyzed qualitatively to get meaning from observed phenomena. Cresswell [5] says that; "Qualitative research is the process of exploring and understanding the meaning of individual and group behavior, describing social problems or humanitarian problems." The whole qualitative purpose is to reach an understanding of how people feel in the process of life, mem gives meaning, and describes how people Installs interpreted experience. Data collection can be done in various settings, various sources, and various ways.

When viewed from the settings the data can be collected in natural settings, in laboratories with experimental methods, in schools with education and education personnel, at home with various respondents, at a seminar, discussion, on the road and others. Data and information that have been obtained by the next researcher are analyzed and interpreted from the beginning of the study until the end of the study by referring to the theoretical foundation that relates to the problem under study. Data analysis in qualitative research is done by classifying, directing, removing unnecessary, and organizing data (reducing data), summarizing the main points (display data) and drawing conclusions (data verification). 


\section{Result and Discussion}

\subsection{Principal Style}

The results showed that the principal's program to improve teacher performance used leadership with a style of openness between subordinates and superiors and if there were things that needed to be discussed then deliberations or discussions would be held to get a way out deliberately with subordinates and superiors at school that is.

\subsection{Implementation of Teacher Performance Improvement Program}

Based on the results of the study it can be concluded that the implementation of teacher performance improvement programs is certainly done by deliberating on what steps will be taken in the future in order to improve teacher performance, and one of them by holding a KKG meeting, guiding teachers to prepare lesson plans, supervise teachers and evaluate teacher performance.

\subsection{Barriers to Implementation of Principal Management}

Obstacles faced in improving teacher performance certainly exist such as the low ability to use electronic devices that can support teacher performance to more powerful things, such as the use of laptops, internet, so that teachers are constrained in getting knowledge or i, you about education that current national and international level.

\section{Conclusion}

With the existence of an appropriate leadership style for the principal, the teacher is more comfortable discussing with the principal. With the principal's program to improve teacher performance, almost all the teachers in the school have improved their performance both in terms of knowledge and from the aspect of awareness in complying with the agreed-upon rules. By knowing the obstacles faced, the principal can evaluate and plan for the future what should be done to improve the quality of learning continuously.

\section{REFERENCES}

[1] Republik Indonesia, Undang-undang republik indonesia nomor 20 tahun 2003 tentang sistem pendidikan nasional. 2003.

[2] E. Mulyasa, Become a professional school principal. Bandung: PT Remaja Rosdakarya, 2013.

[3] E. Karwati and D. J. Priansa, Kinerja dan profesionalisme kepala sekolah. Bandung: Alfabeta, 2013.

[4] S. Sagala, Kemampuan profesional guru dan tenaga kependidikan. Bandung: Alfabeta, 2013.

[5] J. W. Cresswell, Research design pendekatan kualitatif, kuantitatif, dan mixed. Yogjakarta: Pustaka Pelajar, 2012. 